\title{
THE ORIGINS, DEVELOPMENT AND RELIABILITY OF THE ANCIENT TRADITION ABOUT THE FORMATION OF SPARTAN CONSTITUTION
}

\author{
Mait Kõiv
}

\section{I}

Of all the Greek city-states, Sparta offers certainly the most abundant and partly also the best literary evidence about the development of the constitution of an early polis (prior to the 6th century BC). This is true at least in respect of what may be called early documentary evidence. In the first place we have the so-called Great Rhetra, allegedly a Delphic prescription to the Spartan lawgiver Lykourgos, quoted by Plutarch in the biography of Lykourgos as his main constitutional enactment. ${ }^{1}$ By all probability the Rhetra with its commentary derives from Aristotle's lost "Lakedaimonion politeia". ${ }^{2}$ Leaving here aside all the disputes about the exact meaning of particular clauses of the Rhetra, we can summarise its essence as follows. ${ }^{3}$ First, it prescribed the establishment of a new cult (Syllanian Zeus and Athena), the arrangement of the members of the community into structural units (phylai and obai), the establishment of the gerousia of 30 members, including the kings, and the regular holding of assemblies. And second, it prescribed the correct procedure to be followed in the assemblies, leaving the right of the final decision to the people. According to Aristotle, the kings Polydoros and Theopompos added later the so-called Rider to the Rhetra. It gave the gerontes and the kings the right to dissolve the assembly if the people would speak crookedly.

Aristotle quoted also six lines of Tyrtaios. They referred to an oracle, brought from Delphi by unspecified persons, which stated that the political initiative must belong to the kings, then must follow the gerontes, and thereafter the people who must respond with the straight decisions:

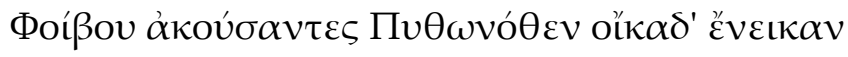

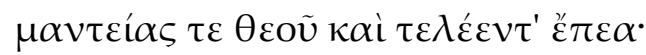

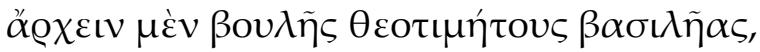

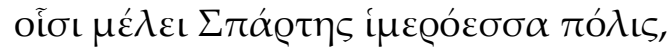

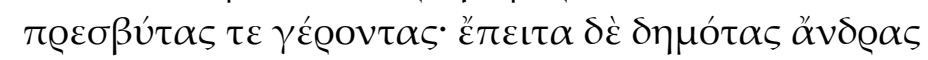

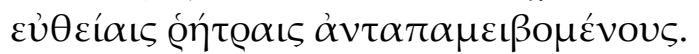

These lines probably derive from the poem called "Eunomia" by the later authors. ${ }^{4}$ They reflect quite closely the prescriptions in the second half of the Rhetra and may be regarded even as Rhetra's paraphrase. According to Aristotle they referred particularly to the fact of the addition of the Rider.

\footnotetext{
${ }^{1}$ Plut. Lyk. 6.

${ }^{2}$ Arist. fr. 536 Rose.

${ }^{3}$ The full text of the Rhetra will be quoted below.

${ }^{4}$ Arist. Pol. 1306 b; Strab. VIII, 362. The identification of the verses as a part of "Eunomia" cannot be proved, but it seems reasonable enough and is generally accepted.
} 
A partially different version of basically the same verses is given by Diodoros, who did not ascribe them to Tyrtaios, considering them to be a Delphic prescription to Lykourgos. ${ }^{5}$ He gives, however, an entirely different beginning, and provides in addition three final lines, that lay some additional stress to the fairness and justice of speech and actions as well as to the power of the mass of the people:

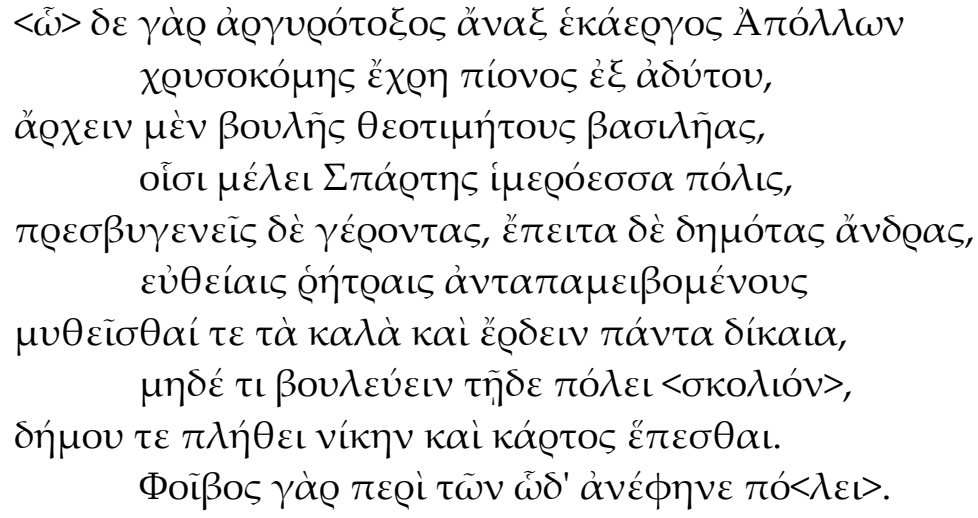

There is no special reason to doubt that the Great Rhetra is a genuine enactment of the Archaic era, ${ }^{6}$ nor is there any ground to deny the authenticity of the lines of Tyrtaios, quoted by Plutarch. ${ }^{7}$ Scholars often admit, justly I think, the lines by Diodoros also as belonging to the Spartan poet. ${ }^{8}$ Since the verses of Tyrtaios reflect the prescriptions of the Rhetra, ${ }^{9}$ they provide for it a solid terminus post quem non (that is, not later than the 7 th century BC). ${ }^{10}$ Thus, the Rhetra and the fragment of Tyrtaios give an early and reliable evidence for the early history of the constitution of a most important Greek state.

In addition to this what may be called contemporary and documentary data, there is the almost over-abundant tradition (most would say pseudo-tradition) about the beginnings of the Spartan state, especially about the great Spartan lawgiver Lykourgos. By all probability, this tradition was presented rather completely already by Ephoros and Aristotle, that is in the 4th century BC. For us it is preserved in the best way in Plutarch's biography of Lykourgos. According to this tradition Lykourgos legislated at an early date, certainly before the Spartan conquest of Messenia. Naturally, this point was shared by Aristotle. He followed the most widespread ancient opinion, dating Lykourgos and the establishment of Rhetra to the time of the king Charillos. The Rider of Theopompos and Polydoros was added, in his opinion, about two generations later (Theopompos was Charillos' grandson) roughly at the

\footnotetext{
${ }^{5}$ Diod. VII, 12.

${ }^{6}$ The scepticism of Trieber 1871, 34ff, Meyer 1892, 261-269 and Meier 1939, 89 is now generally rejected.

${ }^{7}$ This has been, however, denied by Meyer 1892, 227-230 and Ehrenberg 1925, 33.

${ }^{8}$ The authenticity of the verses has been accepted for example by Wilamowitz 1900, 109 n. 3; Hammond 1950, 47-48; Den Boer 1954, 184-193; Bowra 1961, 45; Kieche 1963, 169 (n.1); Hölschner 1986; but contested by Busolt - Swoboda 1920, 48; Jacoby 1918, 7 n. 2; Treu 1941, 35-38; Andrewes, 1938, 95-100; Nafissi 1991, 56.

${ }^{9}$ A different point of view has been expressed by Andrewes 1938, 97-100, who dated the Rhetra after Lykourgos. For Meyer (see n. 6) both the Rhetra and the alleged verses of Tyrtaios were 4th century falsifications.

${ }^{10}$ For the present purpose it is enough to state that Tyrtaios was almost certainly a 7 th century poet.
} 
time of the Messenian conquest. The intention of the kings was, according to Aristotle, to give the gerontes a mean to check the power of too ambitious assembly.

Thus, if we follow the ancient accounts, we should date the establishment of the Spartan constitution certainly not later than the 8th century, ${ }^{11}$ and suppose that at some time around the end of the century, presumably in connection with the Messenian war, ${ }^{12}$ the previously rather extensive power of the damos was checked and the constitution made more aristocratic.

However, all this evidence is nowadays regarded with great suspicion, which amounts almost to its outright rejection as an acceptable testimony. Such point of view is a part of the general scepticism towards the presumably orally transmitted accounts about the Greek Archaic history, and is bound with the realisation of the possible instability of the oral tradition in general. ${ }^{13}$ But it seems that the accounts about the early Sparta are regarded as particularly unreliable. ${ }^{14}$ From the time of U.v. WilamowitzMöllendorff and E. Meyer, ${ }^{15}$ scholars are inclined to regard almost everything the ancients thought to have known about Lykourgos and the early Spartan history as a historically worthless construction of 5th and 4th century authors, based on the voluntary combination of isolated pieces of older texts (mostly poetry), some vague and distorted oral recollections, and often also politically motivated outright inventions. ${ }^{16}$ So it is only natural that one does not pay much attention to Aristotle's beliefs about the establishment of the Rhetra and its Rider. Since the philosopher is thought to have deduced his points of view by the combination of the text of Rhetra and Tyrtaios' poetry with the (historically worthless) legend of Lykourgos, the whole account of the philosopher, including his opinion that the Rider was a later addition to the original Rhetra, is discarded as a secondary construction with almost no value for the reconstruction of the real course of the events. ${ }^{17}$

As a result, one tries to understand the historical circumstances and significance of the establishment of the Great Rhetra almost without any attention to what the ancients themselves thought about it. The scholars rely in their interpretations only on the text of the Rhetra, the verses of Tyrtaios and combine them with their own understanding of the development of the early Greek state and society. ${ }^{18}$ Since one usually follows

${ }^{11}$ Charillos should be dated roughly to the first half or the middle of the 8th century. This is the "modern" dating (see Forrest 1968, 21; Cartledge 1979, 103; Parker 1993, 56). The ancients dated Charillos to the 9th century BC. If we shall prefer the genealogical connections of Lykourgos as presented by Herodotos (see below), we must date him even further past.

${ }^{12}$ The majority of the modern scholars date the war to the closing decades of the 8th century. But see also the suggestions of a slightly lower dating by Beloch 1913, 189; Forrest 1963, 158, 168; 1968, 2122; Parker 1991. The ancients themselves dated the war somewhat earlier (see Jacoby 1902, 188-131; Mosshammer 1979, 204-209).

${ }^{13}$ Finley 1987, 7-27; Ruschenbusch 1992; Fehling 1985. On the nature of the oral tradition in general and its value as the evidence for the past see Vansina 1985. Vansina's conclusions used for the study of the Ancient Greek history: Ungern-Sternberg - Reinau 1988.

${ }^{14}$ Starr 1965.

${ }^{15}$ Wilamowitz 1883; Meyer 1892.

${ }^{16}$ Most recently Nafissi 1991, 51-71; Hodkinson 1997, 83-87; Kennell 1995, 70-97.

${ }^{17}$ Aristotle's sources and the way he used them is discussed most carefully and consistently by Forrest 1963, 157-161 and Nafissi 1991, 51-71. According to the latter, the 4th century authors, Aristotle among them, were basically deceived by propagandistic modifications and inventions of the tradition and poetry by Spartan king Pausanias (see below).

${ }^{18}$ The list of the writings on the character and significance of the Great Rhetra is impressive. I recall here only these that seem to be most important, and the recent ones: Andrewes 1938; Wade-Gery 1958; 
the conception of the gradual democratisation of the Greek city-states - first, the replacement of the monarchies by the aristocratic regiments, and next, the overthrow of these and the establishment of more democratic forms of government - the prescriptions of the Rhetra are adapted in a way or another to such scheme. ${ }^{19}$ And since Aristotle's opinion that the originally rather democratic Rhetra was later complemented by the Rider that added to the powers of aristocratic gerousia, thus making the Spartan constitution more aristocratic than earlier, does not suit such pattern, one is only happy to dismiss it, and to regard the Rider as an organic part of the original Rhetra. The latter is now usually dated to the first half or the middle of the 7 th century. ${ }^{20}$

I hold such approach questionable. ${ }^{21}$ Indeed, we are faced with the fundamental question, how far it is just and necessary to reject the evidence of the ancient tradition about the early Greek history. It seems that modern scholarship has fully developed the argumentation in behalf of the rejection, but left unexplored the possible objections against it. ${ }^{22}$ Hence the object of this paper - to revise the question without any bias against the reliability of the ancient accounts, which has influenced, I think, most of the previous research. The Spartan case with its good documentary evidence and abundant later accounts offers a good possibility for a critical approach, and should be important also because of its significance for the problem of the early history of Greek state.

\section{II}

At the beginning of the discussion we shall briefly outline the development of the opinions of the ancients about Lykourgos and early Spartan history, as far as they can be traced in the extant literary sources.

Rudolph 1956; 1954; Hammond 1950; Den Boer 1954, 153-196; Tsopanakis 1954; Butler 1962; Kiechle 1963, 152-176; Forrest 1967; 1968, 41-55; Jones 1966; Oliva 1971, 71-102; Bringmann 1975; Levy 1977; Welwei 1979; Ruze 1991; Nafissi 1991, 51-81; Ogden 1994; Thomsen 1996, 30-53. Of these perhaps only Hammond and Den Boer have taken in account what the ancients themselves thought about when and why the Rhetra was established.

${ }^{19}$ Rhetra has been regarded as an enactment of the transmission of power either from the kings to the aristocratic gerousia (Kiechle 1963, 161-162, 175-176; Den Boer 1954, 195-196), or from the kings to the assembly of all Spartiates (Rudolph 1956, 66-70; Tigerstedt 1964, 55-58; Bringmann 1975, 531537).

${ }^{20}$ Forrest 1963; Jones 1966; Jeffery 1978, 117-118; Bringmann 1975; Welwei 1979, 194-195; Cartledge 1979, 131-135; Ruze 1991; Nafissi 1991, 71-81.

21 The approach of the moderns is the more questionable, because the conception of the democratisation of Greek society is essentially based on Aristotle' conception of the general development of the Greek state and society (stated explicitly in Polit. 1297 b, but clearly visible also in the full course of his "Athenaion politeia"). The conception of the philosopher must certainly have been the result of his reflections on the data provided by the tradition. One can certainly doubt if it is methodically correct to adapt the general conception of the philosopher while rejecting the evidence it was built on.

${ }^{22}$ The scholars of Greek history have almost certainly exaggerated with Vansina's opinions about the instability and unreliability of tradition. Vansina did not emphasise so much the shortness of the historical memory, as the need to pay to it due respect and to accept or reject no piece of it without careful examination (see Vansina 1985, 196). For the warnings against the overestimation of the mutability of oral traditions see also Schuster 1988, 68-70. 
Tyrtaios in the 7th century knew the initial conquest of Lakonia by the Herakleids ${ }^{23}$ and the conquest of Messenia by the king Theopompos. ${ }^{24} \mathrm{He}$ also knew that the Spartan constitution was sanctioned by Delphi. ${ }^{25}$ But either he or any other of the early Spartan poets almost certainly did not mention Lykourgos — had they, this would surely have been preserved in the quotations of the later authors. But we have no such quotations. This fact in itself, however, does not testify that the lawgiver was unknown to the poets, as has been assumed. ${ }^{26}$

The tradition about Lykourgos was certainly known at the beginning of the 5th century, when the poet Simonides mentioned the lawgiver. ${ }^{27} \mathrm{We}$ are told that according to Simonides, Lykourgos was the son of the king Prytanis, the brother of the next king Eunomos and passed his legislation during the reign of Eunomos' son Charillos. So we find that Simonides followed basically this version of Lykourgos' genealogical connections, and dating that from the middle of the 4th century became canonical among the ancients. Simonides had good relations with influential circles at Sparta, ${ }^{28}$ and we may guess that the version he related was accepted by the Spartans of his time.

In Herodotos we find the tradition already in a rather developed form. Herodotos knew that Lykourgos established eunomia instead of the previous kakonomia, set up all important Spartan institutions, gerousia and ephors among others, and was blessed by Pythia. He knew also that according to some, Pythia prescribed Lykourgos the whole Spartan kosmos, but claimed that the Spartans themselves did not agree, saying that the lawgiver brought the institutions from Krete. And last, Herodotos gave a pedigree of the lawgiver that certainly differed from that suggested by Simonides. In his account Lykourgos was the guardian of the Agiad king Leobotes instead of the Eurypontid Charillos. So Herodotos "dated" the lawgiver in a more distant past. ${ }^{29}$

After Herodotos ${ }^{30}$ the sophist Hippias from Elis ascribed to Lykourgos the establishment of Spartan military institutions. ${ }^{31}$ But two of his contemporaries Hellanikos and Thoukydides — left Lykourgos unmentioned. However, when Thoukydides recalled the change from the state of kakonomia to eunomia in Sparta more than 400 years before his time, ${ }^{32}$ he presumably kept in mind the Lykourgan

\footnotetext{
${ }^{23}$ fr. 1a. GP.

${ }^{24}$ fr. $2-4$ GP.

25 fr 1 b, 14 GP.

${ }^{26}$ Rudolph 1956, 65 n. 1.

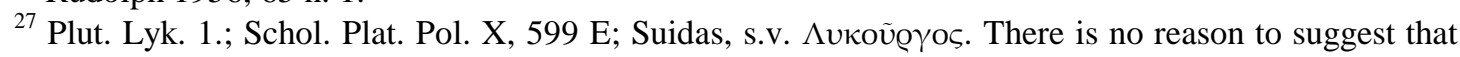
the Simonides in question was, despite the clear statement of Plutarch, not the poet but a minor genealogist from the middle or the second half of the 5th century BC (so Meyer 1892, 276-277 and several other scholars following him). As far as I can see, the suggestion is dictated only by the wish to deprive the tradition about Lykourgos of an early witness. On the role of the historical recollections in the archaic poetry see Rösler 1990.

${ }^{28}$ Note his relationship with the regent Pausanias (Plat. Ep II, 311 A; Plut. Mor 105 A; Ael. Var. hist. XI, 41).

${ }^{29}$ Hdt. I, 65

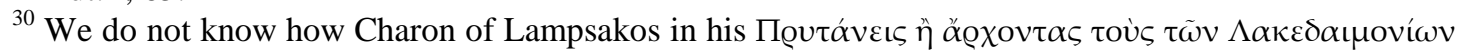
(FGrH $262 \mathrm{~T}$ 1) treated the early history of Sparta and whether or not he wrote something about Lykourgos. However, the lack of any quotations makes it probable that he did not say anything important for the following generations.

${ }^{31}$ FGrH 6 F 7.

${ }^{32}$ Thuc. I, 18, 1.
} 
legislation. But Hellanikos almost certainly ignored it, ascribing the establishment of Spartan institutions to the first kings Eurysthenes and Prokles. ${ }^{33}$ He was thus the first author known to us who mentioned the legislation at Sparta right after the Dorian invasion, an instance mentioned later by several others.

Roughly at the same time - in the turn of the 5th and 4th centuries - the Spartans themselves had a hot debate about their kosmos. There were several pamphlets written on this subject, ${ }^{34}$ and one of them, that of the expelled king Pausanias, certainly touched the character of the Lykourgan legislation. ${ }^{35}$ The king regarded Lykourgos as belonging to the Eurypontid royal line, thus connecting him probably with the king Charillos, and quoted also Delphic utterances to the lawgiver. There are good grounds to believe that these oracles were later taken over by Ephoros, and are preserved for us in the work of Diodoros. ${ }^{36}$ Among these utterances there was the extended version of the verses of Tyrtaios cited above. Thus Pausanias, by all appearance, had identified this piece of poetry as a Delphic prescription to Lykourgos.

The 4th century authors outside Sparta - Isokrates, Plato and Ephoros — generally made a distinction between two stages of arrangement in early Lakonia: first the settlement immediately after the coming of the Herakleids that brought about the reduction of perioikoi to their subjected status and the distribution of the land among the spartiates, and next the Lykourgan legislation somewhat later. ${ }^{37}$ In other words, the point of view of Hellanikos about the settlement of the first kings was matched with the tradition about Lykourgos. When Xenophon dated Lykourgos to the time of the first Herakleids, ${ }^{38}$ he obviously put these instances simply together. The whole scheme of the two stages of arrangement was elaborated in full by Ephoros. In his account the first settlement, the subjugation of perioics and establishment of the status of helots was accomplished by the king Agis one generation after the invasion, while Lykourgos legislated and established eunomia at the time of Charillos several generations later. In Ephoros we also have first time the legend of Lykourgos in its full canonical form. Its principal points were the guardianship of Charillos, emigration, wanderings, meeting with Homer, return, visit to Delphi, legislation, voluntary exile after the Spartans had given an oath to make no changes in his laws before his return, and finally the death abroad, to prevent any alteration in the legislation. ${ }^{39}$

On one point, however, the version of Ephoros seems to have diverged from the later canonical picture. Ephoros seems to have followed his predecessors in ascribing the

\footnotetext{
${ }^{33} \mathrm{FGrH} 4 \mathrm{~F} 116$.

${ }^{34}$ See FGrH 581, 582, 583, 596; Tigerstedt 1964, 110-112.

${ }^{35}$ FGrH 582. I will leave open the much debated question of whether the book was written about

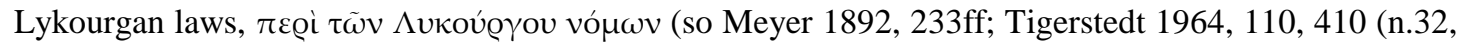

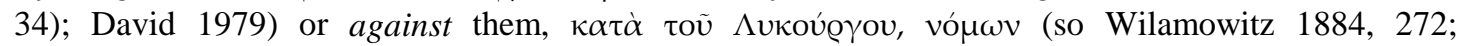
Ehrenberg, 1925, 13-14; Jacoby, FGrH III b1 618-619, b2 361-362; Forrest 1968, 126; Nafissi 1991, 60-61).

${ }^{36}$ Diod. VII, 12. The point cannot be proved, but since Ephoros certainly quoted the pamphlet of the king and Diodoros almost certainly relied on Ephoros in his description of the history of early Sparta, the identity of the oracles in Diodoros with these quoted by Pausanias is universally and I think justly accepted (Meyer 1892, 215-233; Schwartz 1903, 678; Jacoby, FGrH III B a 690-692, b1 616-617; b2 360-361; Tigerstedt 1964, 212-213; David 1979, 109ff; Nafissi 1991, 55).

${ }^{37}$ Isocr. Panathen. 177-179, 153-154; Plat. Nom. 684, 691-692. On Ephoros see note 39.

${ }^{38}$ Xen. Lac. pol. 10, 8.

${ }^{39}$ FGrH 70 F 117, 118, 149, 173-175.
} 
creation of the institution of ephors to Lykourgos, ${ }^{40}$ while according to the point of view that became predominant from the middle of the 4th century, the ephorate was created by the king Theopompos roughly two generations later. This opinion can be traced first in Plato ${ }^{41}$ and was adapted also by Aristotle. ${ }^{42}$

Aristotle's account can be regarded as a summary of the evidence available in his time. He accepted the biography of Lykourgos as it has been presented by Ephoros and became canonical for the later generations. But he provides also some information unknown for us from the earlier sources. He related that Lykourgos had been a companion of the Elean Iphitos in the establishment of the first Olympic games, dating him consequently to ca. $776 \mathrm{BC}$, and based his opinion on the disc from Olympia, where both names were inscribed. ${ }^{43}$ On this point he almost certainly differed from Ephoros, who must have dated Lykourgos about a century earlier and apparently did not connect him with Iphitos. ${ }^{44}$ Aristotle was also the first of whom we know that he quoted the Great Rhetra and presented it as the main constitutional enactment of the lawgiver. Indeed, the king Pausanias, and Ephoros in his train, had cited in its place the extended piece of the verses of Tyrtaios. In other words, Aristotle substituted the prose Rhetra for the versified oracle by Pausanias and Ephoros. ${ }^{45}$ As was said before, he believed that the last clause of the Rhetra that gave the gerontes the right to dissolve the reluctant assembly, was not its original part but a rider, supplemented by Polydoros and Theopompos. The central part of the verses quoted by the king Pausanias as the Delphic utterance to Lykourgos, was in Aristotle's account ascribed to Tyrtaios and considered to be referring to the Rider of Polydoros and Theopompos. Thus, Aristotle laid considerable stress on the legislative activity of these kings, who were credited with two important innovations (the establishment of the ephorate and the introduction of the Rider), distinguishing this act as a third stage in the development of Spartan constitution in addition to the regulations of the first Herakleids ${ }^{46}$ and the Lykourgan legislation.

The only essential points in the tradition that might have been added after Aristotle were the Lykourgan land reform and the increasing of the number of the lots by the king Polydoros. These points of view can be traced first in the propaganda of the king Agis IV in the 3rd century. ${ }^{47}$ Plato and probably Isokrates as well had ascribed the system of Spartan land tenure to the first Herakleid kings. ${ }^{48}$ Whether or not it means that they had ignored the Lykourgan regulations in this field, ${ }^{49}$ and how this question was resolved by Ephoros and Aristotle, remains unclear. ${ }^{50}$

\footnotetext{
${ }^{40}$ Our evidence on this point is indirect. According to Strabon (FGrH 70 F 149) Ephoros said that Lykourgos had borrowed his laws from Crete and compared Spartan ephors to Cretan kosmoi.

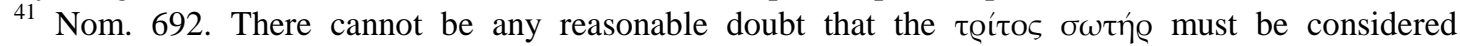
Theopompos.

${ }^{42}$ Arist. Pol. 1313 a.

${ }^{43}$ Arist. fr. 533 Rose. On this point he may have followed Hippias of Elis.

${ }^{44}$ On the dating of Lykourgos see F 149; 173; on Iphitos F 115.

45 There is nothing to support the suggestion of Tigerstedt 1964, 110ff that Aristotle had taken the Rhetra from the Pamphlet of Pausanias. The king has probably relied on the versified oracles instead of the prose Rhetra. Nor can we be certain that the philosopher had used the book of the king at all.

${ }^{46}$ Aristotle certainly must have treated this stage in some way, but unfortunately, we have almost no idea how he had done it. We know that he wrote about some military establishments of the Ageid Timomachos (fr. 532 Rose), but the scholion of Pindaros (ad Isthm. VII, 12) that has preserved this fragment leaves an impression that in his account it occurred somewhat later than the Dorian invasion.

${ }^{47}$ Plut. Agis. 5.

${ }^{48}$ Plat. Nom. 684.

${ }^{49}$ So Hodkinson 1986, 381; Link 1991, 69, 81.

${ }^{50}$ It has been supposed that the "Lykourgan allotment" was either invented or first popularised by
} 
Thus, one must certainly admit that there was disagreement between the sources in several points. But this in itself does not mean that any of the divergent versions was a secondary invention. Most versions we know are recorded quite early. The regulation of the first Herakleids and that of Lykourgos, as well as the divergent versions about Lykourgan genealogy can be traced to the 5th century. And even these points in the tradition that cannot be demonstrated to derive from the 5th century - the measures of Polydoros and Theopompos and Lykourgan land bill - could, in principle, have been divergent versions that have been left unrecorded in the earlier sources. Indeed, the fact that Aristotle was able to quote the Rhetra, not mentioned by the earlier authorities, should warn us from discrediting all the "late" data. Nor does the use of the tradition as an argument in the political debate necessarily imply any essential invention. One should rather assume that the argument was the weightier, the more securely it was based on the accepted beliefs in the society. ${ }^{51}$

All this is not to deny the changes in the tradition nor the possibility that some aspects were invented. But the changes in the details and emphases do not rule out the possibility of the old-inherited and authentic core. The following will be an attempt to consider if there was that sort of thing in Aristotle's account of the early history of Spartan constitution. Or in other words, to what extent can we accept his opinion that the Rhetra reflected some fundamental enactments accomplished before the conquest of Messenia and that the Rider was added by the kings Polydoros and Theopompos. It will be considered, which kind of data the philosopher could and should have possessed, to what extent he had to rely on his own conjectures, and last, what could the data he used have been worth.

\section{III}

First, however, it would be necessary to consider briefly if the text of the Rhetra makes better sense when the Rider would be assumed as its original part or when supposed to be a later addition. Indeed, if the Rhetra would not be intelligible without the Rider, Aristotle's point of view would be discredited. ${ }^{52}$

The text of the Rhetra runs as follows:

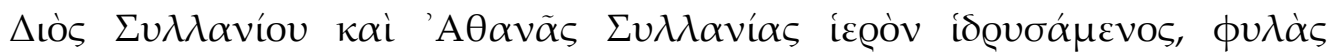

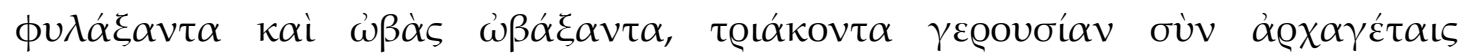

Ephoros (Hodkinson 1986, 381; Link 1991, 81).

${ }^{51}$ In the course of the political debates in the 3rd century Sparta one certainly relied mostly on truths that were accepted already a century before.

${ }^{52}$ It has been tried to discredit Aristotle's point of view by claiming that Aristotle's interpretation of the Rhetra and the Rider is self-contradictory, that according to Aristotle the Rhetra did not give people any right of legal initiative, while the Rider was, in his account, introduced to prevent the changes in the motions by the people, which presupposes that the people had the right (Bringmann 1975, 523; Levy 1977, 101; Ruze 1991, 26). The objection cannot be accepted. In the first place, the ability or inability of Aristotle to give a correct interpretation to the data he presented does nowise affect the worth of the data itself. Aristotle might have known that the rider was supplemented later by the kings and yet failed to establish correctly the reason of its establishment. But in the present case I fail to see any true contradiction in Aristotle's account. He clearly stated that the people had the right to contradict the proposals of the kings and gerontes. And when saying that the people began to change the motions, he did not suggest that it was allowed by the Rhetra but understood it as the trespass of the powers that was to be checked by an additional mean. 


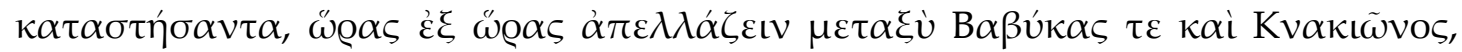

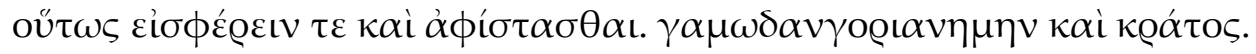

The Kings' Rider:

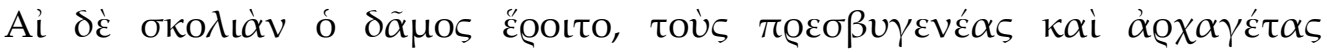
$\alpha \dot{\alpha} \pi \sigma \tau \tau \alpha \tau \tilde{\eta} \propto \alpha \varsigma \tilde{\eta} \mu \varepsilon \nu$.

We do not know who or what was (or were) the subject (or the subjects) of the actions in the Rhetra. ${ }^{53}$ Therefore, the interpretation must depart from the actions themselves. The aorist participles of the first half of the Rhetra express constituting acts: the establishment of the cults, the structural units for the citizens and the council. They lead to the following present infinitives that determined the fundamentals of the political decision-making. The first and logically the decisive of the infinitives is

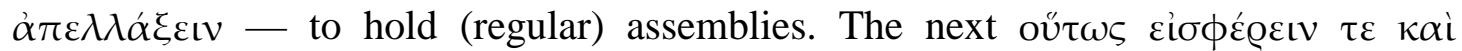
$\dot{\alpha} \phi i ́ \sigma \tau \alpha \sigma \theta \alpha$ เ (to begin with and to end the matter) only say how this should be done, ${ }^{54}$

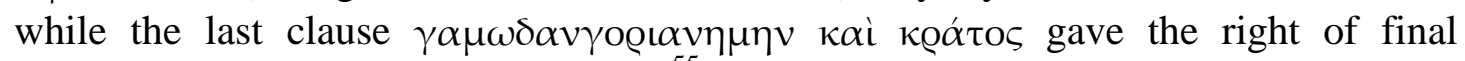
decision to the assembly of the people. ${ }^{55}$ Thus, up to this point the Rhetra is logically directed to establish the regularity of the assemblies and to stress the ultimate authority of the people. ${ }^{56}$

The Rider, from the other side, gives the kings and the gerontes the right to decide if the decisions of the assembly are just or unjust and the power of veto. ${ }^{57}$ So it leaves the final decision to the council, not to the assembly. Thus, the whole ideology of the Rhetra proper and the Rider seems different. Had they belonged together from the start, what sense could it have had to build the whole document up to stress the power of the people, and to declare it void with the last clause? Thus the Rhetra and the Rider certainly make better sense if the latter is regarded as a later addition, made with intention to revise the relations of power in the community in behalf of the council. $^{58}$

\footnotetext{
${ }^{53}$ For the ancients the subject of the aorist participles in the first half of the Rhetra was Lykourgos, that of the following present infinitives remains a matter of conjecture. Modern scholars have sometimes looked for a constant subject through the whole Rhetra, assuming that it must be the kings (so Rudolph 1956, 62; Bringmann 1975, 517-521), or assumed different subjects for the first and the second part (Wade-Gery 1958, 43-49). The ancients certainly should have reckoned with at least two different subjects in the Rhetra, since Lykourgos could not have been imagined as the continuous subject of the present infinitives. But one must also take account of the possibility that the real subject of the motions in the second half of the Rhetra regulating the procedure changed in the course of time. See also the next note.

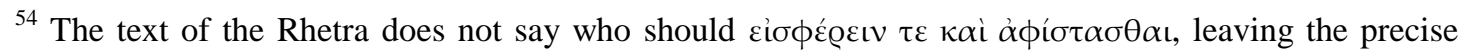
character of the motions rather open. It only points out that the correct procedure should be followed. A good deal of additional information on details was to be known, and this was almost certainly supplemented orally (see Cartledge 1978, 34-35). The formulation of the Rhetra allows various procedures and there is nothing to preclude the possibility that the real procedure changed in the course of time.

${ }^{55}$ No matter how this obviously corrupt passage should be restored, its content is reasonably clear from Aristotle's comment and the last word к@átos.

${ }^{56}$ Tigerstedt 1964, 55, 353 n. 360.

57 The question of the exact meaning of $\alpha \pi \operatorname{\alpha } \tau \tau \alpha \tau \tilde{\eta} \varrho \alpha \varsigma \tilde{\eta} \mu \varepsilon \nu$ as well as the question on which conditions precisely the gerontes were entitled to use their right should not concern us here. The right to decide if these conditions were met was certainly left to gerousia.

58 Tigerstedt 1964, 55-56. The different emphasis of the main part and the rider is stressed also by Ogden 1994, 87. There are, of course, a lot of modern interpretations that try to overcome the

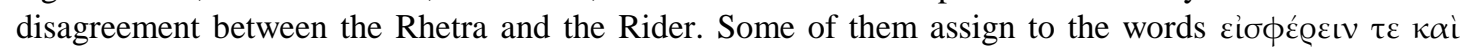


Next the principal question: how could Aristotle have come to his point of view that the Rhetra was established by Lykourgos and the Rider added by Polydoros and Theopompos? Indeed, to ascribe the Rhetra as an act of the establishment of Spartan institutions to Lykourgos was most natural for him. But why did he regard the Rider, that for times should have been an integral part of the Rhetra, as a later supplement, and why did he attribute its introduction to Polydoros and Theopompos?

There are different possibilities. Aristotle could have simply recorded the tradition that the Rider was added by these kings. Or alternatively, he could have known something else about these kings that led him to the conclusion that they must have had a part in giving the Rhetra its definite form. So the philosopher might have separated the Rider from the rest to provide the kings some role by the establishment of the Rhetra. In both cases the information that made him ascribe the Rider to Polydoros and Theopompos must certainly have come outside the text of Rhetra. This information could not have consisted simply of a vague knowledge about the importance of these kings, ${ }^{59}$ but must have been something explicit about their cooperation. Indeed, in the Herodotean list of the Spartan royal genealogies these kings were separated from each other by two generations. ${ }^{60}$ No sensible Greek scholar could have put these figures to act together without any special data on this matter. ${ }^{61}$

In principle, this data could have come from the tradition - a story about the cooperation of the kings in whatever matter. But according to the perhaps most widely accepted modern belief it came from the poetry of Tyrtaios, presumably from the earlier part of "Eunomia". One is inclined to think that Polydoros and Theopompos were the subjects of $\varepsilon v \varepsilon ı \kappa \alpha \nu$ in the first line in the Plutarch's version, which would mean that according to Tyrtaios the oracle was delivered to Polydoros and Theopompos. $^{62}$ If so, there are again two possibilities. Tyrtaios could have quoted it as an approval of the supplement by the kings to an already existing constitution,

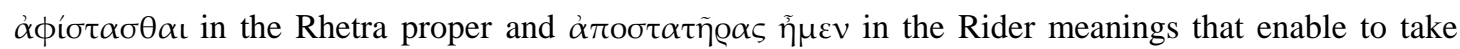
them as standing for the successive stages in the same chain of procedure, making so the Rider its necessary part (Wade-Gery 1958, 47-50; Forrest 1967, 15-17; Ruze 1991, 24-26. See also Tsopanakis

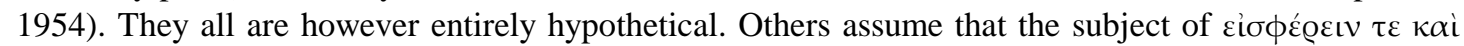
$\dot{\alpha} \phi i ́ \sigma \tau \alpha \sigma \theta \alpha \mathrm{t}$ in the Rhetra is not gerousia as it is in the case of the $\dot{\alpha} \tau \sigma \sigma \tau \alpha \tau \tilde{\eta} \varrho \alpha \varsigma \tilde{\eta} \mu \varepsilon v$ in the Rider, but either the kings (Rudolph 1956, 62; Bringmann 1975, 521) or ephors (Levy 1977, 101-103). So the Rider can be interpreted as giving gerousia the right of final decision in the cases of disagreement between the initiators of the legal motions and the assembly. Such interpretation, however, is contrary to the interplay of gerousia and assembly, clearly visible both in the Rhetra proper (the establishment of gerousia followed by that of the regular assemblies, the statement of gerousia's political initiative followed by that of final decision of the assembly) and in the Rider (gerousia's right to decide about the rightness of assembly's behaviour).

${ }^{59}$ So Rudolph 1956, 65 n. 1.

${ }^{60}$ Compare Hdt. VII, 204 and VIII, 131.

${ }^{61}$ The existence of such data is clearly implied by the fact that somewhere around the middle of the fourth century, the name of the king Soos was inserted in the early part of the Eurypontid stemma, most probably to reduce the difference of the genealogical datings of Theopompos and Polydoros, thus maiking their common action possible.

${ }^{62}$ Hammond 1950, 49; Den Boer 1954, 187-188; Forrest 1963, 158-160; Kiechle 1963, 155-157; Nafissi 1991, 73 . 
roughly in the same way as Aristotle understood the things. ${ }^{63}$ Or alternatively, the poet could have quoted the oracle as a sanctioning of the primary establishment of the Rhetra. In the latter case it would ascribe to the kings the establishment of the whole constitution and one is compelled to admit that, according to Tyrtaios, Polydoros and Theopompos were the authors of Spartan political system. Several modern scholars prefer the second alternative. They think that when Aristotle realised that the poetry of Tyrtaios was in contradiction with the commonly accepted belief about Lykourgos as the author of the Spartan political system, he found no better solution than to separate the last clause of the Rhetra as a rider and ascribe it together with Tyrtaios' verses to the kings, to be able to maintain the Lykourgan origin for Rhetra's main part. ${ }^{64}$ Such point of view would certainly discredit both the opinion of Aristotle, and the general belief of the ancients that the formation of Lykourgan constitution took place before the conquest of Messenia. Instead, it brings its establishment down to the time of Theopompos and Polydoros, presumably slightly after the first Messenian war.

The crucial question is therefore, who was (or were) then the person (or the persons) who, according to Tyrtaios, had fetched the utterances of Apollo? Or to put it differently, who were the subjects of $\varepsilon^{\prime} v \varepsilon \iota \kappa \alpha \nu$ in the poem? Could it have been explicitly stated in the poem that Polydoros and Theopompos had brought the oracle from Delphi?

One must note that Aristotle, when ascribing the oracle by Tyrtaios to the kings, was not very confident on this point. He did not claim that he had learnt about the act of the kings from the text of Tyrtaios. Instead, he seems to have been looking, rather cautiously, for a confirmation and illustration of his pre-existing point of view. After recording that the kings had supplemented the Rider, he stated that "they also persuaded the polis that it (the Rider) was prescribed by the god, as Tyrtaios seems to

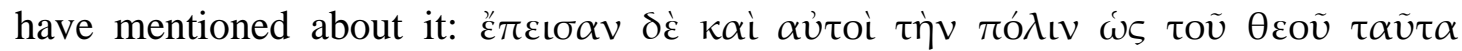

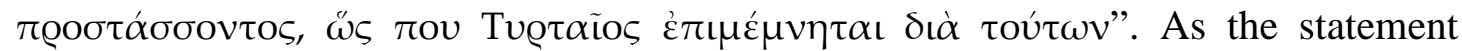
points out, the quotation was made to support his opinion that the kings had claimed that their action was confirmed by Pythia. Thus, Aristotle seems to have hesitated about if the quotation was quite relevant. ${ }^{65}$ The note of hesitation must have concerned either the fact of divine confirmation, or the identity of the persons whose actions were confirmed. Since on the first point any hesitation was ruled out by the

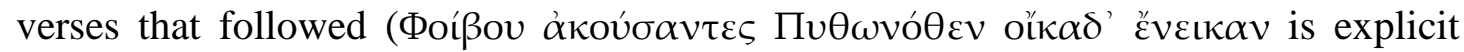
enough), we must admit that the hesitation was applied to the persons, something that was not explicit in the quotation. Thus, the very wording of the passage gives good grounds to think, that Aristotle was not certain about who exactly had, according to Tyrtaios, brought the oracle. ${ }^{66}$

\footnotetext{
${ }^{63}$ So Hammond 1950, 62; Den Boer 1954, 187-188; Kiechle 1963, 166-167.

${ }^{64}$ So Forrest 1963, 165-166.

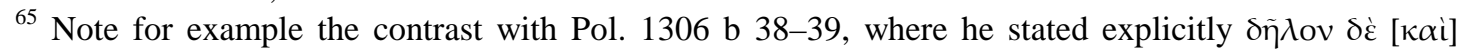

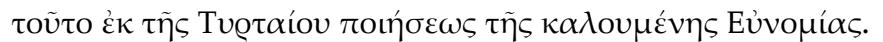

${ }^{66}$ Contra Forrest 1963, 159-160. He claimed that if Aristotle had hesitated about whether Polydoros and Theopompos were the subjects of čveıkav, he would have begun the quotation from their names, and concluded that the hesitation applies to the connection of the oracle and the Rider. The argument would be valid only if it was possible for Aristotle to make a quotation where the names of the kings were explicitly associated with the oracle. But we do not know whether the kings were mentioned in the poem at all, and if they were, then in what context. It could have been just the impossibility to make such a quotation that was the cause of Aristotle's hesitation.
} 
This impression is strongly supported by the fact that the ancients were not unanimous on this point. ${ }^{67}$ We have noted that the same verses as quoted by Aristotle were most probably cited already by the king Pausanias and Ephoros, who, using the beginning that allowed a singular subject, had attributed them to Lykourgos ${ }^{68}$. Had the subject been explicitly stated, how could the different attributions of these verses have been possible? Or were there two principally different versions, ${ }^{69}$ one attributing the oracle to Lykourgos and the other to Polydoros and Theopompos? ${ }^{70}$

It is however almost certain that at least in Sparta the verses could not have been known in a form that explicitly attributed the establishment of Spartan political institutions to Polydoros and Theopompos. We know that the poetry of Tyrtaios was traditionally sung at Sparta on the public occasions, presumably during syssitia. ${ }^{71}$ Consequently, its content must have been well known, and the ideas it expressed commonly accepted. It applies not least to "Eunomia". Indeed, Eunomia has long been a central slogan in the Spartan propaganda. Not only that it was used as the keyword for the Spartan system by the 5th century "foreigners" Herodotos and Thoukydides. It was mentioned already by Alkman, ${ }^{72}$ and was personified by the king Eunomos in the royal stemma. ${ }^{73}$ In this context one must consider also the poem of Tyrtaios. Given the importance of the poetry of Tyrtaios for the Spartan identity, we must assume that the poem must have played a central part in shaping and preserving the attitudes of the Spartans about the past of their institutions. ${ }^{74}$ When singing the

\footnotetext{
${ }^{67}$ This point has been rightly stressed by Nafissi 1991, 54, 70 .

${ }^{68}$ It is obvious from the context were Diodoros presented the verses, even if we dismiss the notice $\mathrm{H}$

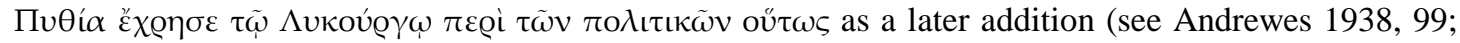
Wade-Gery 1958, 57 n. 4; Tigerstedt 1964, 356 n. 378).

${ }^{69}$ The fact that there was probably no early authorised text of Tyrtaios' verses, has been pointed out already by Wilamowitz 1884, 282 n. 17; 1900, 109. See also Tigerstedt 1964, 57.

${ }^{70}$ From the philological point of view it has been proven impossible to confirm, whether the variants of Diodoros and Plutarch should or should not have belonged together. One has not succeeded in reaching concord on the point whether the common lines of both variants (lines 3-6) require the ending lines by Diodoros (so Wilamowitz 1900, 108; Hammond 1950, 47-48 Den Boer 1954, 156, 188-189; Kiechle 1963, 169 n.1; Hölschner 1986, 417ff), or could be better understood without the addition (so Meyer 1892, 228; Jacoby FGrH III b1 360 (n.4); Andrewes 1938, 98; Wade-Gery 1958, 61). I take the very existence of the disagreement for the proof that neither possibility is ruled out.

${ }^{71}$ Lyk. Leocr. 107; Philochoros FGrH 328 F 216; Plat. Nom. 629b. On the transmission of the poetry of Tyrtaios in Sparta, see Cartledge 1978, 27-28, on the role of syssitia in Spartan society Hodkinson 1983, 251-254, and on the historical recollections in symposian poetry Rösler 1990.

${ }^{72}$ Alkman fr. 64 Page.

${ }^{73}$ This king is obviously a fictive figure, but as an early fiction (mentioned already by Simonides), it demonstrates the importance of the notion of eunomia in the Archaic Sparta.

${ }^{74}$ It has sometimes been argued, pace the explicit statements of the ancients, that the poetry of Tyrtaios should have been virtually unknown at Sparta before the 4th century (Jacoby 1918, 5ff; Kiechle 1963, 223; Schwartz 1899, 466-468 considered them Athenian inventions from the 4th century). The arguments are, first, that before the 4th century the contemporaneity of Polydoros and Theopompos that should have been apparent from Tyrtaios was unknown (as demonstrated by the Spartan royal stemmas by Herodotos), and second, that according to Herodotos the Spartans were not aware of the Delphic origin of their kosmos, which was explicit in Tyrtaios' "Eunomia". Neither of the arguments can be accepted. The first of them takes for granted that the knowledge of the contemporaneity of the kings was derived from the poetry of Tyrtaios, something we cannot be sure about. Above all, it confuses the knowledge of the co-actions of some persons and the scholarly use of this knowledge for genealogical and chronological calculations (see Forrest 1963, 161 n. 25). Against the second argument one must note that the Spartans certainly had close connections with Delphi from early Archaic times suggested by the stories about the Spartan requests of Pythia in the Archaic period (Hdt. I, 66-67; Euseb. Praep. Ev. 5, 32). Note also the cult-states of Pythian Apollo at Thornax and Sparta (Paus. III, 10, 8; 11, 9). Indeed, Herodotos admitted that the Spartans were well aware that Lykourgos was blessed by Pythia
} 
verses or listening to them, one must have had an idea of what they were about. And this idea must have conformed to their stories about the past. In other words, the attitudes of the Spartans about their past could not have been in open contradiction with the poetry of Tyrtaios. Had Tyrtaios ascribed the creation of the political system to Theopompos and Polydoros, there should have been correspondingly a strong tradition associating the establishment of Rhetra and eunomia with these kings. One might even ask what possibilities there could have been then for the formation of the tradition about Lykourgos. Or at least one should have considered Lykourgos a contemporary and co-actor of Polydoros and Theopompos. But we have no traces of the existence of such traditions. The Rhetra, prescribing the establishment of gerousia, was and could have been connected only with Lykourgos - indeed, as far as we can see, all the ancients regarded gerousia as a Lykourgan establishment. And all the ancients who had something to say about it dated Lykourgos and eunomia unanimously before Polydoros and Theopompos. ${ }^{75}$

So we have good grounds to suggest that the Spartans regarded the oracle in the verses of Tyrtaios as a Delphic prescription to Lykourgos, ${ }^{76}$ and when the king Pausanias published it as such, he followed the common opinion of his compatriots. ${ }^{77}$ Thus, if one wants to maintain the existence of principally different versions, it should be admitted that the one ascribing the oracle to Lykourgos was current at Sparta, while the other that connected it with the kings was known outside. ${ }^{78}$ But all this is to create unnecessary difficulties — the need to explain their origins and transmission. ${ }^{79}$

(the oracle in Hdt. I, 65). The Delphic connections of the lawgiver were thus certainly accepted by the Spartans. When Herodotos noted the polemic of the Spartans against the alleged Delphic origin of their kosmos and their claim that it derived from Crete, he kept in mind rather the origin of their social institutions and upbringing, that certainly were similar to these at Crete, not the lack of the blessing of the Delphic god to the Spartan political system. In other words, Herodotos' opinion might have been in fact quite similar to that of Ephoros (F 149) On the knowledge of the poetry of Tyrtaios in the Archaic Sparta see also Schachermeyr 1932, 130-131.

${ }^{75}$ There is of course the statement of Thoukydides (I, 18, 1) about the beginning of eunomia a little more than 400 years before his time, which has been taken as dating it 10 generations back (40 years for a generation), that is to the time of Theopompos (Den Boer 1954, 84; Huxley 1962, 100 n. 49; Forrest 1963, 172). Such interpretation is extremely uncertain and, I think, groundless. We do not know what exactly these 400 years were about (a suggestion that it was 12 generations of 33,3 years and lead so to Charillos, seems not the least probable; but see also Mosshammer 1979, 179), but since we have no clear indications on the contrary, it would be certainly reasonable to think that Thoukydides did not diverge from the common opinion that eunomia was established by Lykourgos before the time of Theopompos and Polydoros.

${ }^{76}$ If the Spartans assumed Polydoros and Theopompos as the subjects of $\varepsilon^{\prime} v \varepsilon t \kappa \alpha v$, they could not have seen in these verses the reference to the Rhetra, but must have connected them with some post-Rhetran development, roughly in the same way as Aristotle. In such case Aristotle's point of view was obviously correct. I hold the suggestion however rather improbable, because it presumes that Pausanias, when attributing the verses to Lykourgos, was trying to change radically the Spartans' understanding of the poem.

${ }^{77}$ Pace modern suggestions (Meyer 1992, 215-236; Jacoby, FGrH III b 1, 618-619; Nafissi 1991, 5171), Pausanias did not have free hands in manipulating neither the traditions nor the verses of Tyrtaios, if he wanted to be taken seriously by his compatriots. He must have been always counting on what the Spartans knew and believed on these points.

${ }^{78}$ In such case we have almost no possibility to decide, which of these versions, if either, was better (or "more authentic").

${ }^{79}$ It has been suggested that the variant of Diodoros is a secondary elaboration, perhaps composed or rather ordered to be composed by the king Pausanias for the needs of political propaganda (Schwartz 1903, 678; Jacoby, FGrH III b 1, 618-619; Nafissi 1991, 56). I find the suggestion both improbable and unnecessary. It would mean, first, that this crucial poem of the Spartan "national" poet was previously unknown at Sparta, but known abroad (see also note 74), second, that Pausanias, when getting aware of 
In fact, there is no reason to suggest that such principally different versions ever existed. It is obvious that the variants of Diodoros and Plutarch can be reconciled. ${ }^{80}$ They could have been simply different combinations of the different parts of a long poem. And if we take into account the hesitation of Aristotle in his interpretation, it would be certainly reasonable to admit that the text of Tyrtaios simply was not explicit on the point of who exactly brought the oracle from Delphi. ${ }^{81}$ The words of Tyrtaios must have been ambiguous enough to make possible the different attributions of the same oracle.

Consequently, Aristotle could not have learnt about the activity of Polydoros and Theopompos unambiguously from the poem of Tyrtaios. The pair of the kings could well have been mentioned in the poem, and the fact that Aristotle thought they were

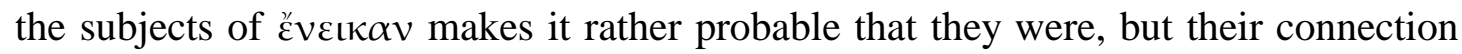
with the oracle could have been only a matter of guess. Aristotle nevertheless made the connection and gave so the poem an interpretation different from that of Pausanias and Ephoros. Could he have relied in this only on his own interpretation of Tyrtaios' text, or must he have possessed also some information outside the poem? And what other information on this point he could have had?

\section{V}

We know, that in the late antiquity the Spartans connected both Theopompos and Polydoros in a way with the development of their political and social system. There was the story that Theopompos was the creator of ephorate while Polydoros was remembered as a popular king, who increased the number of the lots of the Spartiates and was subsequently murdered because of his democratic attitudes. Indeed, there was even the monument of his murderer, a certain Polemarchos. ${ }^{82} \mathrm{We}$ also know that in Spartan agora, right before the house of gerousia, there stood the monument of Theopompos. ${ }^{83}$ There was also a monument of Polydoros, his house was shown to the visitors and his image was depicted on the Spartan state-seal. ${ }^{84}$ All this testifies that they were considered to be important figures in the development of Spartan institutions.

It is, however, very difficult to say how much of all this corpus of information was older than Aristotle and could have been known to and used by him. But there were at

it, made a falsified version to deceive his compatriots, and third, that he was able to deceive also Ephoros, who, as an outsider, should have known the true version, but nevertheless accepted Pausanias' invention. Nor have I seen any good explanation of the causes that should have made such elaboration useful for the king. The different opening lines that allow a singular subject could have been necessary to ascribe the oracle to Lykourgos (so Parke Wormell 1956, 90; Nafissi 1991, 56), but the need for the falsified continuation remains unclear (I cannot accept the ingenious but groundless suggestion of Schwartz 1903, 678 and Jacoby 1918, 7 n. 2, FGrH III b 1, 618-619 that excludes lines 5 and 6 from Pausanias' (Diodoros') version and considers it to be referring to a pre-Lykourgan constitution).

${ }^{80}$ See the different suggestions by Blumenthal 1948, 1947-1949; Tsopanakis 1954, 68-80; Hölschner $1986,419$.

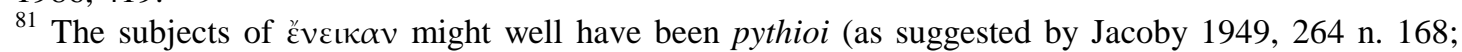
Rudolph 1956, 65 n. 1) or the kings (Rudolph, loc. cit.) or Herakleidai (Andrewes 1938, 100), or it might have been simply left rather open (Parke Wormell 1956, 90). See also below.

${ }^{82}$ Paus. III, 3, 3.

${ }^{83}$ Paus. III, 16, 6.

${ }^{84}$ Paus. III, 11, 10; 12, 3. 
least two instances that he must have been aware of. First, he must have known from the poetry of Tyrtaios that Theopompos was the king who had conquered Messenia. And second, he certainly knew that Theopompos had established the institution of ephors. Indeed, that was mentioned already by Plato. Aristotle recorded not only the supposed act of the king, but also a story about how he had justified the act to his reproaching wife. ${ }^{85}$

Aristotle could certainly have possessed more information about the king. But one might equally suggest that this was all he knew, but still enough to make him inclined to attribute to the king some other constitutional changes as well. In this case the reliability of Aristotle's account could be seriously questioned. Since the earlier sources seem to have known nothing about Theopompos as the creator of the ephorate, but had ascribed the establishment of the institution to Lykourgos, it can be suggested that the Theopompos version was a groundless invention. And if this invention, coupled with the knowledge about Theopompos as the conqueror of Messenia, had influenced Aristotle to make the king an even more important legislator, to see in him one of the subjects of $\varepsilon^{2} v \varepsilon \iota \kappa \alpha v$ in Tyrtaios and consequently to separate the Rider from the Rhetra to give the king something additional to do in the development of Spartan constitution, then the conception of the philosopher would be historically worthless.

So we are led to two related questions: first, whether it is probable that Aristotle's knowledge about Theopompos was confined only to these points that we can be certain about, and second, where should we look for the origins of the tradition about Theopompos as the creator of ephorate and how reliable this tradition was.

One cannot contest the possibility that this tradition might have been invented, perhaps by the king Pausanias, as has been suggested. ${ }^{86}$ But here we are faced with the same kind of problem as in the case of the separation of the Rider. The inventor must have had a reason to attribute it to this particular figure. We cannot help ourselves with the suggestion that it was deduced by comparing the date of the beginning of the list of ephors (754/3 BC) with that of Theopompos' reign (785/4-

\footnotetext{
${ }^{85}$ Arist. Pol. 1313 a. It can be taken for granted that the anecdote was not invented by the philosopher. Aristotle could have been deceived by his sources and guilty of unwarranted conclusions, but there is no ground to suggest that he went on to fabricate a story (on Aristotle's methods see Day Chambers 1962, especially 5-23 on Aristotle's use of the sources, and Huxley 1973). So there can be no doubt that the version about Theopompos as the establisher of the ephorate could not have its origins "im Kreis um Aristoteles" (Kiechle 1963, 231), but must have been given to the philosopher by his sources. The principal idea of the tale, that the limitation of the power of the kings by the institution of ephorate was necessary to make kingship more lasting, underlies the conception of Plato as well. We can assume that both philosophers had followed principally the same tradition, perhaps even interpreted the same story.

${ }^{86}$ Meyer 1892, 244-250; Nafissi 1991, 63-71; Hodkinson 1997, 85. Pausanias certainly was in opposition with ephors (Arist. Pol. $1301 \mathrm{~b}$ ), and so he might have tried to reduce their authority by claiming that the institution had not been a part of the true Lykourgan constitution, but was supplemented later. Such suggestion in itself does not stand on a very strong ground. It can be accepted only if the book of Pausanias was written $\pi \varepsilon \varrho i \tau \tilde{\omega} \nu \Lambda v \kappa o u ́ \varrho \gamma o v$ vó $\mu \omega v$. If it was directed against the Lykourgan laws, as many scholars have thought (see note 35), it would have been nonsense on Pausanias' part to contest the Lykourgan origin of the ephorate. And there remains the question, why Ephoros, who seems to have used and followed the work of Pausanias, nevertheless ascribed the creation of the ephorate to Lykourgos. But even if the point of view is to be accepted, it does not answer t4he question, why it was precicely Theopompos, who was sought out as the creator of this institution.
} 
$139 / 8 \mathrm{BC}$ according to the chronicle of Apollodoros).$^{87}$ Indeed, we cannot be sure if a list of ephors beginning from 754/3 BC was ever available for such a comparison and if so, when it was composed. ${ }^{88}$ And we know that the dates of the ephors and the regnal years of the kings were first synchronised only by Timaios in the 3rd century BC. ${ }^{89}$ It is decisive, however, that the synchronism of these instances simply could not have been perceived early enough to give ground for the emergence of the tradition. The date 754/3 fell within the supposed time of Theopompos' reign only when a fictitious king Soos was inserted in the early part of the list of the Spartan Eurypontid kings. Without counting Soos, Theopompos should have been dated a generation earlier. ${ }^{90}$ Soos was, as far as we know, first counted by Ephoros. ${ }^{91}$ Earlier, in Plato, Soos had not yet been regarded as a king but simply as a noble Lakonian. ${ }^{92}$ Thus, it was only from the time of Ephoros that the connection of the institution of ephors with Theopompos could have been deduced from the synchronisation of the beginning of the list of ephors and the time of Theopompos' reign. But the ephors were assigned to Theopompos already by Plato, thus before Ephoros. ${ }^{93}$ And it goes without saying that the considerations of Ephoros could have nowise influenced the discussion at Sparta at the time of the king Pausanias. Indeed, Ephoros, whose work must have given ground for the connection of Theopompos and the institution of ephors, had not himself made such conclusion.

All this means that the point of view, that the tradition about Theopompos as the creator of the ephorate was a result of chronological calculations, must be rejected. We are compelled to assume that even if the tradition was invented, the inventors should have had some knowledge about the importance of the king, that in their eyes made him the best suitable figure for it. And this importance could scarcely have confined to his role as the conqueror of Messena. From the time of Aristotle, at latest, the supposed importance of Theopompos in the matters of Spartan inner development was coupled with that of Polydoros. Indeed, the kings were believed to have been contemporaries. This circumstance must be also accounted for and it certainly cannot be explained only by the knowledge of Theopompos' Messenian exploits. There must almost certainly have been more information. There are two possible sources where it could have come: the oral tradition and the poetry of Tyrtaios. As we know, the kings could have been mentioned by Tyrtaios, possibly even as a pair, and this could have been used as an evidence by the ancients. But this does not make unnecessary an assumption of the existence of oral tradition. Rather on the contrary. We must keep in mind that Tyrtaios' poetry was not a dead word known only in some narrow circles, where it could have been used freely either for voluntary political propaganda or for

\footnotetext{
${ }^{87}$ So Neumann 1910, 119; Szanto 1905, 2860; Kiechle 1963, 225ff, more cautiously also Tigerstedt 1964, 61; Oliva 1971, 125. On the ancient datings of the establishment of the ephorate and of the reign of Theopompos see Jacoby 1902, 88.

${ }^{88}$ Doubts about the existence of the list that began 754/3 have been expressed by Jacoby 1949, $282 \mathrm{n}$. 55; 305 n. 24; Mosshammer 1979, 89.

${ }^{89}$ Polyb. XII, 11, 1.

${ }^{90}$ I cannot go here into detailed discussion of Ephoros' genealogical chronology. It is enough to state that in the 4th century, as is demonstrated by Isocr. Archid. 27 (with the support of Diod. VII, 12 who could have represented the data of Ephoros), the Spartan conquest of Messenia, and so inevitably Theopompos as well, was dated to the early part of the 8th century.

${ }^{91}$ In Ephoros' account Lykourgos was the 6th from Prokles (F 149; 173), which is possible only when Soos was counted.

${ }^{92}$ Plat. Cratyl. 412 B.

${ }^{93}$ The work of Ephoros could certainly not have been published before the late 350ies (see Schwartz $1907,1)$, thus not before Plato's death.
} 
scholarly research. As said, it was above all a matter of Spartan national pride and an important mean of Spartan self-identification. What was in the poetry must have always been in the minds of the Spartans. And that means, that if the kings were mentioned by Tyrtaios, there should have been also a corresponding tradition. The Spartans must certainly have had some ideas what it was that Tyrtaios was singing about and expressed them in their stories. In other words, the mentioning by Tyrtaios in fact requires the existence of the tradition as well. A tradition might have existed without any supporting notice by Tyrtaios, but an assertion of Tyrtaios scarcely without corresponding beliefs the mind of the Spartans. And these beliefs must have derived from a true tradition, not from a politically motivated ad hoc invention from the early 4 th century. ${ }^{94}$

Some kind of tradition about Theopompos and Polydoros, probably supported by Tyrtaios' verses and not confined only to Theopompos' exploits in the Messenian war must have, consequently, existed already before the beginning of the politically and scholarly motivated speculations of the 4th century. This tradition must have been distinct from that about Lykourgos. It could have been elaborated and embellished both during the 4th century and later, so that we cannot be sure about what exactly the tradition consisted of before this time. But we can be almost certain that it did exist. ${ }^{95}$ And there is no reason to doubt that it was known to and used by Aristotle.

In other words, besides the stories about Lykourgos, the text of the Rhetra and the poetry of Tyrtaios, Aristotle must have known also some traditionally based account about the role of the kings Theopompos and Polydoros in the development of the Spartan state. From all this he framed a comprehensible and what he himself thought an adequate history of Spartan constitution. The poetry of Tyrtaios, particularly the Eunomia-poem could have provided him a kind of general framework for the arrangement of the data. Indeed, we know that according to the poem, Zeus himself had given the land to the Herakleids, ${ }^{96}$ that is to the Spartan kings, to rule. The poem recalled also the prescriptions of Pythian Apollo (note the mentioning of the pythio $i^{97}$ ) and praised the divinely sanctioned constitution: the power of the kings, gerontes and the people. ${ }^{98}$ It had also something to say about the inner unrest at Sparta during the Messenian war. ${ }^{99}$ As said before, the poem could have mentioned some acts of Polydoros and Theopompos. And there are certain grounds to think that the praise of Theopompos as the conqueror of Messenia ${ }^{100}$ came from this poem, too. ${ }^{101}$ By all probability the poem implied also some sequence of these instances that could have

\footnotetext{
${ }^{94}$ From all that has been said it is obvious that I cannot accept the point of view about the pamphlet of the king Pausanias as the turning point in the formation of the ideas about the early development of Spartan constitution (stated recently again by Nafissi 1991, 51-71). The single and corrupt passage in Strabon (VIII, 366) that we have about this book certainly does not warrant the far-reaching speculations it has inspired. See also n. 78.

${ }^{95}$ That some kind of tradition really did exist, is obviously implied by the fact that Aristotle has a story to tell about Theopompos as well as by the abundance of the later stories and monuments concerning and commemorating the actions of both kings. Without making the highly improbable suggestion that all this had its basis in Aristotle's learned constructions in "Lakedaimonion politeia" we have to admit that it relied on a tradition that was independent of and presumably prior to the philosopher.

${ }^{96}$ fr. 1a GP.

${ }^{97}$ Ibidem.

${ }^{98}$ fr. 1b, 14 GP.

${ }^{99}$ Arist. Pol. 1306 b.

100 fr. 2 GP.

${ }^{101}$ See Jacoby FGrH III b 2, 360 n. 3; Walter 1993, 166-169.
} 
been worked on by the philosopher. For instance, in Plato we find partly rather similar stages in the early Spartan history as mentioned by Tyrtaios: ${ }^{102}$ Zeus had given the land to the Herakleid kings and instituted the double kingship, then "a human being mingled with divine power" made the system more stable by establishing the power of gerontes, and last, a "third saver" checked the excessive power of the kings by the establishment of ephorate. Indeed, it is not very different from the conception of Aristotle, who also regarded the establishment of ephorate as a measure to limit the royal power and distinguished a stage of development after Lykourgos, something that seems to have been missing in Ephoros and the earlier historians. Could it be that the logic of development described by the philosophers was based on their closer reading of Tyrtaios? Perhaps some rather vague expressions used by Plato could also have derived from this source? If so, then the poem could have given a critical scholar like Aristotle both the general framework for the arrangement of available data as well as enough ground for hesitation about how exactly it should have been arranged.

In any way, Aristotle had not entirely free hands by the interpretation and combination of the data he had. The Rhetra and the poetry were known to the Spartans as well, and the way the Spartans understood them, expressed in their local stories, must have been in its outline known to Aristotle and so in a way binding for him. Thus, when Aristotle interpreted his data, he must have been influenced by basically the same stories that the Spartans knew and believed in, which means that the results of his interpretation could not have been very different from Spartans' own picture of their past.

The same thing applies also to the role Aristotle assigned to Polydoros and Theopompos. If the kings were mentioned by Tyrtaios, so that the passage of the poet could have been used by Aristotle as an evidence, then it could not have been interpreted by him in a drastically different way from how the Spartans themselves understood it. Or alternatively, if the kings were not mentioned, and Aristotle had to learn about their importance from the tradition, he again must have reflected the beliefs of the Spartans. So, whatever the case, Aristotle could scarcely have assigned the kings the acts very different from what they were credited with by the Spartans themselves. We have therefore good grounds to assume that already before Aristotle the Spartans had believed that the kings Polydoros and Theopompos made some changes or contributions to Lykourgan constitution.

Aristotle certainly treated the tradition critically and could have "corrected" to a certain extent. But its general outline must have been left basically unchanged and we cannot deny the possibility that even the particulars of the picture had, at least in part, remained the same. Indeed, if there was a tradition about some legislative acts of the kings, as we know that there should have been, then it would be certainly reasonable to assume that it consisted of basically the same acts that were assigned to the kings by later authors. Or in other words, one cannot exclude the possibility that already before the 4th century the Spartans had believed that Theopompos had something important to do with the institution of ephorate, that together with Polydoros he had supplemented on the Lykourgan Rhetra, and that Polydoros was responsible for certain changes in the system of the land tenure after the conquest of Messenia. There is no special reason to wonder that we have no mention of these instances before

${ }^{102}$ Nom. 691-692 (see also 683). 
Aristotle, and that Polydoros' allotment of land can be documented only from the 3rd century. They all could have been well known at Sparta and simply left unnoticed by the non-Spartan writers. Even the points of view that the institution of ephors was a part of the Lykourgan constitution and that it was established later by Theopompos, could have existed side by side at Sparta. Nor are they entirely incompatible, since one could well have thought that the king had added to the power of an already existing institution. ${ }^{103}$ However it was, Aristotle was probably the first scholar to undertake the task of writing the history of Spartan constitution with due care, and there is no wonder that he was able to present some versions unrecorded by most of his predecessors.

\section{VI}

And now the last problem: where should we look for the origins of the traditions that were current in the Classical Sparta and what was their historical worth?

We know that the tradition that Lykourgos had established eunomia did exist at least from the end of the Archaic era (as testified by Simonides), and the tradition about Theopompos and Polydoros prior to the beginning of the intense discussion on the history and significance of Spartan constitution in the late 5th and early 4th century. We also know that the Spartans had been proud of their eunomia already since the archaic era, as it can be safely assumed from the fragments of the poetry of Tyrtaios and Alkman, as well as from the existence of the king Eunomos in the royal stemma. And in addition we know that from the 7th century onwards the Spartans had sung the verses of Tyrtaios, which praised the establishment of their supremacy and order. All this framed the understanding of the Spartans of the origins of their present state of affairs. Obviously, the Spartans must have tied these instances together in some way, or at least these instances could not have, in their opinion, openly contradicted each other. Thus, the poetry of Tyrtaios could not have been perceived as contradicting either the tradition about Lykourgos or that about Theopompos and Polydoros. On the contrary, when the Spartans sung the poems of Tyrtaios about the beginnings of their state, they must have taken it as a confirmation of what they knew from other sources. When Tyrtaios praised the establishment of eunomia, the Spartans must have understood it as a praise of Lykourgos, since everyone knew that he was responsible of this act. And when Tyrtaios paraphrased the Rhetra, it must have again reminded the Spartans of their lawgiver. The beginning of eunomia, the establishment of the Rhetra, and the acts of Lykourgos must have been the same thing for the Spartans.

From this simple assumption we must proceed when asking about the origins of the tradition about Lykourgos. The problem is, how could the tradition have emerged when Tyrtaios, already in the 7th century, had sung about the beginning of the Spartan order and so given a mythology of the origins? Or in other words, why should the Spartans have invented the tradition about Lykourgos, when a picture of the formation of their state was already in a way sanctioned by the poetry of Tyrtaios? Even if we suggest that in the 6th century there was a change in the Spartan constitution,

\footnotetext{
${ }^{103}$ Perhaps it is not without significance, that Plato (Nom. 692), who provides the earliest testimony,

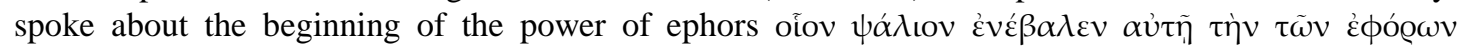
$\delta v v \alpha \mu \imath$, something that does not exclude the possibility that the institution was believed to have existed already before that moment.
} 
something I cannot quite believe in, ${ }^{104}$ that brought along a radical reshaping of the traditions, we must still suppose that the reformers tried to justify their acts by manipulating the already accepted beliefs in the society rather than inventing entirely new figures and versions. Thus, even if the tradition about Lykourgos was invented around this time, ${ }^{105}$ the inventors must have looked for support from Tyrtaios. But what support could they have found there? We know that his poems sung about the first Herakleids, praised the exploits of Theopompos, possibly also recalling his common actions with Polydoros, but they almost certainly did not make any mention of Lykourgos. Thus, the poetry of Tyrtaios could have given occasion to assigning the creation of the Spartan system to several persons, but almost certainly not to Lykourgos. The poetry of Tyrtaios simply could not have induced the rise of the tradition about Lykourgos. So the tradition must have risen independently. And since after Tyrtaios the picture of the Spartan origins he had given in his poetry would virtually have precluded the emergence of some entirely new version about the past, ${ }^{106}$ we are almost compelled to conclude that the tradition about Lykourgos did already exist when Tyrtaios composed his poems.

The case of Theopompos and Polydoros is somewhat different. Tyrtaios certainly mentioned Theopompos, and as we know, the poet might have recalled also something the king had accomplished together with his colleague Polydoros. Thus, the corresponding tradition could have found direct support from his poetry. But it also means that already in the time of Tyrtaios, the kings were considered worth of mentioning in the context of the development of Spartan institutions. Alternatively, if Tyrtaios did not mention Polydoros or anything else about Theopompos than his Messenian exploits, then we must, as in the case of Lykourgos, assume the existence of an oral tradition independent of and presumably prior to his poetry.

In any case, neither the tradition about Lykourgos nor about Polydoros and Theopompos could, probably, have been invented after the time of Tyrtaios. When Tyrtaios sung, he and his auditory must have already known something about the legislation of Lykourgos and must have considered Polydoros and Theopompos somehow important in the development of their state. They must also have had an understanding of how the acts of the kings and this something they knew about Lykourgos were related to each other. From this time onwards the poetry of Tyrtaios has conferred for the Spartans the message about their past. And in the classical period this message consisted of the tradition that Lykourgos had once established

104 A radical ("Lykourgan") change of Spartan constitution in roughly this time was suggested by Dickins 1912, 17-26; Wade-Gery 1925, 562 (who dated it to the late 7th century); Ehrenberg 1925, 10; 1929, 1381. This conception was based on the archaeological data, mainly from the sanctuary of Artemis Orthia in Sparta, that seemed to suggest a radical decline of Spartan crafts in the 6th century. Such interpretation has proved in many parts fallacious. Therefore, one speaks now about gradual transformation (Holladay 1977, 111-114; Cartledge 1979, 159; Stibbe 1996, 12-13). Hodkinson 1998 has questioned the very existence of the 6th century decline in Sparta. In this way the concept of the 6th century "reform" is deprived of his main support.

${ }^{105}$ So Jacoby FGrH III b, 1 357-362. I find the suggestion incredible. We should then believe that the hypothetical reformers completely denied their own merits, something that obviously contradicts almost everything we know about the temper of the Archaic Greeks (one needs only to recall Solon's presentation of himself), that they invented a previously unknown lawgiver (but why should it have been necessary?) and that they were so successful with their scheme, that after a century everyone accepted their invention as a truth and the memory about them as the true reformers has been completely faded.

${ }^{106}$ On the cultural norms that regulate the debate concerning the past see Appadurai 1981. 
their eunomia and the kings Theopompos and Polydoros had later improved upon it. Is there any positive reason to suggest that the Spartans had not thought so already in the 7 th century?

Indeed, Tyrtaios could not have regarded the establishment of eunomia as a contemporary or recent development, ${ }^{107}$ nor could he have connected the beginning of eunomia with Theopompos and Polydoros. Had it appeared in his poems in either of these ways, no tradition of an early Lykourgan legislation could have emerged. So we must conclude that for Tyrtaios and his auditory the establishment of eunomia was an act of rather distant past, ${ }^{108}$ accomplished by Lykourgos, distinct from the enactments of Theopompos and Polydoros and taken place before these kings.

These considerations throw some light on the origins and significance of the Great Rhetra. We have all grounds to believe that its general content was known to Tyrtaios and his contemporaries. Since it was arranged as the constituting act of the Spartan state, it must have been always regarded as the mark of the establishment of eunomia. Indeed, the formation of Spartan constitution and the establishment of eunomia have been always regarded as almost synonyms. And since at the time of Tyrtaios the establishment of eunomia was regarded as belonging to the past, one must have dated the Rhetra in the same way. Nor is there any ground to suggest that it was ever attributed to someone else than Lykourgos - the figure always identified as the author of Spartan eunomia.

Thus, the Spartans in the 7th century must have believed that, times ago, Lykourgos had established their cults, arranged their forefathers into phylai and obai, formed the council of 30 members including the kings, prescribed the holding of regular assemblies, and left the final decisions to this body. This act must have been regarded as the beginning of their divinely sanctioned eunomia. They must have also believed that Polydoros and Theopompos had later confirmed this order. And all these beliefs must have found an expression in the exhortative verses of Tyrtaios, who recalled the virtuous past as an example for the stabilisation of the turbulent present.

This does not mean that the text of the Rhetra must have been written down already before the 7th century. The document in the form that we know could well have been produced at the time of Tyrtaios or perhaps even later. But the idea it expressed must have been familiar to the Spartans at the time of Tyrtaios. And from the very moment of its composition it must have been considered "Lykourgan". This, however, means in turn that, pace all modern scepticism, Lykourgos must have been the implicit subject of the actions in the first part of the Rhetra. ${ }^{109}$

\footnotetext{
107 So Wade-Gery 1958, 67; Bowra 1961, 45-46. But it would be nonsense to assume, that Tyrtaios tried and succeeded to convince his auditory that the reform of the present time had in reality taken place in the past, unless there was already an accepted belief in an old constituting act that could have been recalled as an example for the present. Consider also the poetry of Solon where the reforms that might have been intended to confirm traditional values and conditions (so Mitchell 1997, 137) were presented unambiguously as contemporary accomplishments.

${ }^{108}$ The idea that the verses of Tyrtaios were intended to refer to a settlement of distant past has been expressed by Andrewes 1938, 99-100, Parke - Wormell 1956, 90, and Tigerstedt 1964, 58.

${ }^{109}$ If we accept such conclusions, some otherwise unclear circumstances will be readily explained. If Tyrtaios recalled several instances of the past, the establishment of eunomia and the acts of Polydoros and Theopompos among others, but did not explicitly mention Lykourgos and depicted the kings as the confirmers of what had been established earlier, then one must not wonder that his poetry was
} 
Certainly the picture that the 7th century Spartans had about their past must have a good deal of historical worth. Tyrtaios and his contemporaries should have known quite well what had happened at the time of their grandfathers, when Theopompos and Polydoros were kings. They could scarcely have confused their acts with the establishments of the previous generations that were summarised as "Lykourgan" Rhetra. Thus, the Rhetra must be probably regarded as an archaic, presumably 7th century summary of the understanding of the Spartans about the beginning of their state in a not quite recent past. It is well possible that the acts it contained had in reality taken place during a considerable time. But we must nevertheless admit that by all probability they had taken place before the Spartan conquest of Messenia.

\section{VII}

There is no reason, then, to suggest that the tradition about the formation of the Spartan state was on any essential point frankly invented. It is certainly true that oral traditions do not remain unchanged in the course of the transmission. Social memory is selective and the traditions are always re-adapted to suit and justify the changing conditions. ${ }^{110}$ So we must expect certain re-arrangement of the traditions in the times of important changes in the society. But in the case of Sparta the main formative period that must have left a decisive impact to the whole Spartan society and way of life was, as far as we can judge, the time of the conquest of Lakonia and Messenia, that is the 8th and 7th century. During the rest of the Archaic and most of the Classical period there seems to have been a rather gradual development within the same social and constitutional framework. So we must suppose that the formation of the traditions about the beginnings also took place during this early time, not later than Tyrtaios, and was thereafter transmitted without further radical changes. ${ }^{111}$ Indeed, the development that had taken place before Tyrtaios remained essential for the self-identification of the following generations and must have been worth of remembering. ${ }^{12}$ But in addition, the Spartans had Tyrtaios' poetry, which reflected

interpreted differently by the classical authors. The Spartans, the king Pausanias among them, took it as self-evident that the verses paraphrasing the Rhetra must apply to Lykourgos, while a critical scholar like Aristotle could well have found that the particular stress the poet lied upon eutheiai must point rather to the Rider. We can now also understand the different datings and genealogical connections of Lykourgos. However divergent they were, they all share the tendency to connect the lawgiver in some way with the beginning of the state. The difference lays only in how this "beginning" was understood. The most common version connected Lykourgos with Charillos — the king who seems to have been the first historical member of the Eurypontid house, so perhaps the first about whom the tradition had something substantial to say (on the point of view that Charillos was the first historical Eurypontid king see Forrest 1968, 29; Jeffery 1978, 114; Cartledge 1979, 106), Herodotos thought that the lawgiver was a contemporary of the founder of the Agiad dynasty (Leobotes was the son of Agis, consequently Lykourgos must have been in this account Agis' brother - see Meyer 1892, 276), while Xenophon dated him simply to the very start of the history of Dorian Sparta. All this finds explanation, if we admit that Tyrtaios had placed the beginning of eunomia in a distant but unspecified past and regarded it at the same time as the true beginning of the Spartan state and order.

${ }^{110}$ Vansina 1985, 100-123.

${ }^{111}$ Note the supposition of Vansina 1985, 168 that the main process of selection and structuring of the traditions occurs in the first and the second generation of transmission.

112 One can compare the abundance of the traditions about the beginnings (in addition to Lykourgos the stories about Minyans or other Lemnian immigrants (Hdt. IV, 145-149; Nic. Dam. FGrH 90 F 28; Konon 36. 46; Plut Mor. 247. 296), about Aigeidai (Schol. Pind. Pyth. V, 69. 76; Isthm VII, 12), about parthenioi (see Sakellariou 1990, 66-93), the accounts by Pausanias (III, 2, 1-3, 4; 7, 1-5)) with the 
and expressed these traditions, was by all likelihood of constantly great importance for Spartan ideology, must have given a kind of framework and pledge for the transmission of the traditions and precluded the invention of entirely new versions about the past.

During the 4th century, the history of Spartan institutions was certainly discussed from political as well as scholarly viewpoint. One is therefore justified to suppose that certain modifications took place. Indeed, the propagandistic disputes in Sparta about its past could have brought about some inventions. But these inventions could not have been ex nihilo creations, but must have elaborated inherited and generally accepted traditions. Certain changes could have been brought about also by the writers outside Sparta, not least by Aristotle, who could have made some "precisions" and reinterpretations when comparing and combining the traditions he knew with the available documentary evidence. For instance, there are good grounds to think that he was the first to suggest that the oracle that was referred to in Tyrtaios" "Eunomia" should be attributed to Polydoros and Theopompos instead of Lykourgos. But the evidence Aristotle used - Rhetra, poetry and oral traditions - must have been already arranged in a way by Spartans, and this must have influenced the philosopher, who was therefore bound to reflect quite well what his contemporary Spartans thought about their past.

All this is not to claim that the accounts of the ancient historians must be taken at their face value. There cannot be much doubt that the "biography" of Lykourgos was formed according to a mythological cliché: the birth as a younger brother, thus almost as an outcast, exile turned out as voyages indispensable for a sage that brought him together with other famous figures; the divinely sanctioned power after the return; and last, the death somewhere away. ${ }^{113}$ We do not know, when the formation of such "biography" took place - its basic points might well have been known already to Tyrtaios - , but it scarcely tells us much about any historical Spartan lawgiver. Nor can there be any doubt that Lykourgos, and possibly Theopompos and Polydoros as well, served as "culture heroes" for the Spartans, and were probably credited with the accomplishments that in reality took place at different times and under different circumstances. ${ }^{114}$ Indeed, the Great Rhetra itself, as a 7th century summary of the events of rather distant past, can be regarded as a result of such kind of telescoping. And of course, there is no need to contest that the ideas about Lykourgos as well as about Theopompos and Polydoros were later used as arguments in the political disputes, in which case some political desire of the present could have become a "historical reality" of the past. But the changes and inventions must have gone on from what was already accepted. They must have sought their support from the tradition and, consequently, in only exceptional cases could they have brought about fundamental changes in the ideas about the past. These cases must be certainly demonstrated. It is not enough to state that something in our accounts can be invented; one must always ask what compels us to suggest that it really was.

virtual lack of the accounts about the 7th and early 6th century, something that well accords with Vansina's "the traditions of the beginnings — the floating gap" model (Vansina 1985, 23-24, 168169).

${ }^{113}$ On the clichés in the oral traditions see Vansina 1985, 137-146.

114 On "culture heroes" in general see Vansina 1985, 106. On Solon as a "culture hero" for Athenians Thomas 1898, 280; Shapiro 1996, 132. 
Thus, there is no reason to discard Aristotle's conclusions as worthless constructions. He stands in the lower end of a rather continuous chain of transmission, and gives us, at least, a valuable starting-point for the reconstruction of the tradition and in this way of the events it was concerned about. He was, by all probability, well informed about the data on the development of Spartan constitution available in his time and must have been in many ways better prepared than we are to make judgements about the transmission and the worth of particular accounts. And we have good grounds to believe that his conclusions about the early Spartan history were not drastically different from the opinions of the Spartans of the Archaic era. Already at the time of Tyrtaios Spartans had believed that a great man called Lykourgos had once established their eunomia, something summarised in the Great Rhetra, and that somewhat later the kings Theopompos and Polydoros had made further contributions to the constitution, in order to confirm Lykourgos' establishments. And this, in turn, could not have been very far from historical truth. 


\section{References}

Andrewes, A. (1938), Eunomia, in: CQ, 32. 89-102.

Appadurai, A. (1981), The Past as Scarce Resource, in: Man, 16. 201-219.

Beloch, K. J. (1913), Griechische Geschichte, Bd. I, Abt. 2., Strassburg.

Blumenthal, A. v. (1948), Tyrtaios, in: RE, II Reihe, 14. 1941-1956.

Bowra, C. M. (1961), Greek Lyric Poetry, Oxford.

Bringmann, K. (1975), Die Grosse Rhetra und die Entstehung des spartanischen Kosmos, in: Historia, 24. 513-538.

Busolt, G. - Swoboda, H. (1920), Griechische Staatskunde, Bd. I, München.

Busolt, G. - Swoboda, H. (1926), Griechische Staatskunde, Bd. II, München.

Butler, D. (1962), Competence of the Demos in the Spartan Rhetra, in: Historia, 11. 385-396.

Cartledge, P. (1978), Literacy in the Spartan Oligarchy, in: JHS, 98. 25-37.

Cartledge, P. (1979), Sparta and Lakonia, London.

David, E. (1979), The Pamphlet of Pausanias, in: PP, 34. 94-116.

Den Boer, W. (1954), Laconian Studies, Amsterdam.

Day, J. Chambers, M. (1962), Aristotle's History of Athenian Democracy, Berkeley, Los Angeles.

Dickins, G. (1912), The Growth of Spartan Policy, in: JHS, 32. 1-42.

Ehrenberg, V. (1925), Neugründer des Staates, München.

Ehrenberg, V. (1929), Sparta (Geschichte), in: RE, II Reihe, 6. 1373-1453.

Fehling, D. (1985), Die Sieben Weisen und die frühgriechische Chronologie. Eine traditionsgeschichtliche Studie, Bern, Frankfurt am Main, New York.

Finley, M. I. (1987), Ancient History. Evidence and Models, Penguin.

Forrest, W. G. (1963), The Date of the Lykourgan Reforms in Sparta, in: Phoenix, 17. 157-179.

Forrest, W. G. (1967), Legislation in Sparta, in: Phoenix, 21. 11-19.

Forrest, W. G. (1968), A History of Sparta. 950-192 B.C., London.

Hammond, N. G. L. (1950), The Lycurgean Reform at Sparta, in: JHS, 70. 42-64.

Hodkinson, S. (1983), Social Order and the Conflict of Values in Classical Sparta, in: Chiron, 13. 239-281.

Hodkinson, S. (1986), Land Tenure and Inheritance in Classical Sparta, in: CQ, 36. 378-406.

Hodkinson, S. (1997), The Development of Spartan Society and Institutions in the Archaic Period, in: The development of the Polis in Archaic Greece (Ed. L. G. Mitchell, P. J. Rhodes), London, New York, 83-102.

Hodkinson, S. (1998), Lakonian Artistic Production and the Problem of Spartan Austerity, in: Archaic Greece, New Approaches and New Evidence (Ed. N. Fisher, H. v. Wees), Duckworth, 93-118.

Holladay, A. J. (1977), Spartan Austerity, in: CQ, 27. 111-126.

Hölschner, U. (1986), Tyrtaios über die Eunomie, in: Studien zur alte Geschichte. Siegfried Lauffer zum 70. Geburtstag, B. II, Roma.

Huxley, G. (1962), Early Sparta, London.

Huxley, G. (1973), Aristotle as Antiquary, in: GRBS, 14. 271-286.

Jacoby, F. (1902), Apollodors Chronik (Philologische Untersuchungen 16.), Berlin.

Jacoby, F. (1918), Studien zu den älteren griechischen Elegiker, in: Hermes, 53. 1-44.

Jacoby, F. (1949), Atthis: The Local Chronicles of Ancient Athens, Oxford.

Jeffery, L. H. (1978), Archaic Greece. The City-States c. 700-500 B.C., London. 
Jones, A. H. M. (1966), The Lykurgan Rhetra, in: Ancient Society and Institutions. Studies Presented to V. Ehrenberg, Oxford, 165-175.

Kennell, N. M. (1995), The Gymnasium of Virtue. Education and Culture in Ancient Sparta, Chapel Hill, London.

Kiechle, F. (1963), Lakonien und Sparta, München, Berlin.

Levy, E. (1977), La Grande Rhetra, in: Ktema, 2. 85-103.

Link, S. (1991), Landverteilung und soziale Frieden im archaischen Griechenland, Stuttgart.

Meier, T. (1939), Das Wesen der spartanischen Staatsordnung, Leipzig.

Meyer, E. (1892), Forschungen zur alten Geschichte, Bd. I, Halle.

Mitchell, L. G. (1997), New Wine in Old Vessels: Solon, Arete and the Agathos, in: The development of the Polis in Archaic Greece (Ed. L. G. Mitchell, P. J. Rhodes), London, New York, 137-147.

Mosshammer, A. A. (1979), The Chronicle of Eusebius, Lewisburg, London.

Nafissi, M. (1991), La nascita del Kosmos. Studi sulla storia a la società di Sparta, Perugia, Neapel.

Neumann, K. J. (1910), Die Entstehung des Ephorats und König Theopomp, in: E. Kessler, Plutarch's Leben des Lykurgos, Berlin.

Ogden, D. (1994), Crooked Speech: the Genesis of the Spartan Rhetra, in: JHS, 114. 85-102.

Oliva, P. (1971), Sparta and her Social Problems, Prague.

Parke, H. W. - Wormell, D. E. W. (1956), The Delphic Oracle, Oxford.

Parker, V. (1991), The Dates of the Messenian Wars, in: Ciron, 21. 25-47.

Parker, V. (1993), Some Dates in Early Spartan History, in Klio, 75. 45-60.

Rösler, W. (1990), Mnemosyne in the Symposion, in: Sympotica. A Symposium on Symposion (Ed. O. Murray), Oxford, 230-237.

Rudolph, H. v. (1956), Die lykurgische Rhetra und die Begründung des spartanischen Staates, in: Festschrift Bruno Schnell. Zum 60 Geburtstag, München, 61-76.

Ruschenbusch, E. (1992), Zur Genese der Überlieferung über die archaische Zeit Griechenlands und das 5. und 4. Jh. v. Chr., in: Historia, 41. 385-394.

Ruze, F. (1991), Le conseil et l'assemblée dans la Grande Rhetra de Sparte, in: REG, 104. 15-30.

Sakellariou, M. B. (1990), Between Memory and Oblivion, Athens.

Schuster, M. (1988), Zur Konstruktion von Geschichte in Kulturen ohne Schrift, in: Ungern-Sternberg, J. v. Reinau, H. (1988), 57-71.

Schachermeyr, F. (1932), Tyrtaios, in: RM, 81. 129-142.

Schwartz, E. (1899), Tyrtaeos, in: Hermes, 34. 428-468.

Schwartz, E. (1903), Diodoros, in: RE, 9. 663-704.

Schwartz, E. (1907), Ephoros, in: RE, 11. 1-16.

Shapiro, H. A. (1996), Cults of Solonian Athens, in: The Role of Religion in the Early Greek Polis (Ed. R. Hägg), Stockholm, 127-133.

Starr, C. G. (1965), The Credibility of Early Spartan History, in: Historia, 14. 257272.

Stibbe C. M. (1996), Das andere Sparta, Mainz am Rhein.

Szanto, E. (1905), Ephoroi, in: RE, 10. 2860-2864.

Thomas, R. (1989), Oral Tradition and Written Record in Classical Athens, Cambridge.

Thomsen, L. (1996), Lakedaimonion Politeia, Stuttgart.

Tigerstedt, E. N. (1964), The Legend of Sparta in Classical Antiquity, Vol. I, Stockholm, Göteborg, Uppsala. 
Treu, M. (1941), Der Schlusssatz der Grossen Rhetra, in: Hermes, 76. 22-42.

Trieber, C. (1871), Forschungen zur spartanischen Vefassungsgeschichte, Berlin.

Tsopanakis, A. G. La rhetre de Lucurgue - l'annexe - Tyrtée (Hellenika, Suppl. 6.), Thessaloniki.

Ungern-Sternberg, J. v.; Reinau, H. (Hrsg.) (1988), Vergangenheit in mündlichen Überlieferung, Stuttgart.

Vansina, J. (1985), Oral Tradition as History, London, Nairob.

Wade-Gery, H. T. (1958), Essays in Greek History, Oxford.

Walter, U. (1993), An der Polis teilhaben, Stuttgart.

Welwei, K.-W. (1979), Die spartanische Phylenordnung im Spiegel der Grossen Rhetra und des Tyrtaios, in: Gymnasium, 86. 178-196.

Wilamowitz-Moellendorff, U. v. (1900), Textgeschichte der griechischen Lyriker, Berlin. 